\title{
Dynamics of Change and Displacement in Chinua Achebe's Arrow of God
}

\section{Nirupa Saikia}

Associate Professor, Govt Aizawl College,Aizawl,Mizoram, India

E- mail: nirupasaikia@yahoo.com

\begin{abstract}
The fictions of Chinua Achebe, one of the most celebrated African writers, are indicatives of his concern for the changing African society and culture. Arrow of God, his third novel, traces the transitional pattern of human civilization in an Igboland in Southeastern Nigeria. By embedding the social, religious, political and cultural reality at the core of his novel, Achebe focuses on the succession of civilizations, of epochal cycles in which each civilization collapses and makes way for the successive one. The impact of the British colonial invasion that served as a catalyst in the process of transition is recounted by Achebe with a rare sense of detachment and objectivity. While the seed-time of the progressive colonial, topsyturvydom is explored in Things Fall Apart, his first novel, Arrow of God presents the second phase of decline in the traditional society in terms of transition from the traditional religion to an alien one. In Arrow of God, Achebe offers an insightful portrayal of the social and religious life of the Igbo people in the throes of change. Here Achebe is neither condemning nor extolling the infiltration of the white man, his culture and religion. Christianity is shown to have been embraced by the Africans due to the inherent weakness in the structure of the traditional Igbo society.
\end{abstract}

Keywords-Christianity, Displacement, Igbo, Nigeria, Religion.

\section{INTRODUCTION}

Chinua Achebe has chosen Africa, especially Nigeria, its people, their peculiar world view and way of life as the creative space of his writings. He is essentially a writer who is preoccupied with his society, its history, the disintegration of indigenous culture and native values, to put in other words, with the destiny of his people. As the fundamental feature of his novels is social realism, they serve as an authentic record of the changing African world. The paper attempts to analyse the process of change and the consequent displacement of the indigenous religion by Christianity as presented by Achebe in his third novel Arrow of God (1964). The brilliant recreation of the transitional point of shifting from the old religious order to a new one endows a unique and universal appeal to the novel. The comprehensive picture of the Igbo world in spiritual and materials terms, the crumbling of the traditional religion under the external as well as the internal forces establishes Achebe as an insightful literary artist par excellence.

\section{DISCUSSION}

Arrow of God, set in southeast Nigeria in the 1920s, about twenty years after Africa's confrontation with the west, records a time when the presence of the church and the missionary school in a Nigerian village was an accepted reality along with people's adherence to the traditional Igbo religion. The traumatic experience of the Igbo people due to colonialism is the main concern of Achebe in his first and third novels set in the traditional past. In the context of Arrow of God, Sola Soile states:

To be sure the destructive colonial forces that we encounter in the first novel are still very much alive and thriving, but they now stand on the periphery of the doomed society, waiting on the wing to swoop down, like vultures, the moment the society commits harakiri. ( Soile 283 )

A theme of this sort provides scope for analysing the strength and integrity of the society. To depict such a personal world view, Achebe sets time and setting of his novel at a point where religion played a pivotal role in the society. The rise and fall of the communal god and his chief priest are at the centre of the novel. While maintaining the 
ethnographic exactitude, Achebe also attempts to create his personal world as directed by his theme.

The spiritual beliefs and values of the Igbo people presenteded in Arrow of God provide the authentic background to the novel.The faith in the existence of Chukwu, the high god, personal god Chi, Ekwensi, the spiritual embodiment of evil, nature deity Ota, Eru, the god of wealth and other protective deities of villages like Udo, Idemili, Ogwugwu and other gods of Umuaro and Ogba of Anita, forms the structure of the indigenous religious creed. At the centre of the novel, Achebe places Ulu, the common deity of the six villages constituting Umuaro and his priest Ezeulu, the intermediary between the human world and the spiritual world. Ulu is comparatively a new god, without much mystery or taboo, created at the time when the six villages - Umuachala, Umunneora, Umuagu, Umuezeani, Umuogwugwu and Umuisiuzo united for protection against slave raids of the aggressive neighbour, Abam.

Obviously the traditional religion was not exclusively concerned only with the spiritual life of the Igbo people. The myth of divinity was founded on human realities as Ulu was created to serve the community, to maintain the dignity and well-being of the whole society. Wole Soyinka's comment is significant in this context:

In Achebe's work, the gods are made an expression of the political unity (and disunity) of the people. Their history or measure (or both) testifies to their subjection to secular consciousness... The deity Ulu came into being as a result of a security decision, an expression of the survivalist will of the human community. (Soyinka 92)

Although dealing with a religious theme, Achebe is not concerned much with the mythical or theological aspect of any religion. Hence Arrow of God is free from any kind of doctrinal confrontation between Christianity and Igbo religion. The society oriented framework of the novel has made Achebe's religious approach rather humanistic. He is mainly analyzing the individual and socio-political factors leading to the fall of Ulu, the eventual tragedy of the priest and the people's ultimate resort to Christianity deserting their traditional religion.

The character of Ezeulu is perceived in the novel as a spiritual leader who is in close communion with the spiritual world. He is a divine spokesman, an intermediary between man and his deity and a spiritual saviour of his community. In addition, he plays an important role in the material life of his community by performing the rituals of two most important social ceremonies - the Festival of the Pumpkin Leaves and the New Yam Feast. In the first ceremony, Ezeulu, being Ulu's representative, cleanses the village of their sins before the planting season. He performs necessary rituals of the other major ceremony, the New Yam Feast, which marks the end of the old year and the beginning of the new. In this ceremony the union of the villages is re-enacted and every grown-up person in Umuaro takes a seed-yam to the shrine of Ulu and places it in the heap from which Ezeulu selects thirteen to calculate the new year.

The complex relationship between a god and his priest is explored by Achebe through Ezeulu's relation with Ulu:

Being the arrow in "the bow of his god," half man, half spirit, an entirely African-derived concept of priesthood, Ezeulu is conscious of himself as the carrier of the god's truth, as the one who must bear the heavy burden of decision, as a scapegoat to bear all the sins of the people, as one ready for the symbolic sacrifices regularly demanded by the deity. ( Vargo 286 )

Ezeulu, the priest of the community, is expected to interpret Ulu's will for the prosperity of the community. But he fails to fulfill their expectations due to his strong individualism and personal motives. As a man of broad vision and comprehensive outlook, capable of foreseeing the future and as an intellectual with penetrating insight and ambition for power, Ezeulu seeks to explore and exploit his priestly power to the fullest extent. His ambition for power and his firm individual perception of religious duty are shown in conflict with the communal perception of religion and priestly responsibility. As the novel begins, we meet a discontented and perplexed Ezeulu surveying the limits of his power. The analysis begins as he waits for the appearance of the new moon to eat the sacred yam. His inability to exercise his personal will in the fixation of dates for the Pumpkin Leave Festival and the Feast of New Yam leads him to wonder whether he is merely a watchman for the god's decision or more than that. The mere thought that he dare not take independent decision fills him with intense anger : "No man in all Umuaro can stand up and say that I dare not. The woman who will bear the man who will say it has not been born yet" (Arrow of God 3). Still he is troubled by the illusory and passive nature of his priestly power: "What kind of power was it if it would never be used?"(4).The Chief Priest is thus exposed as one striving to 
conserve and advance his power over his community which was once entrusted to him for their protection only. His consideration of the self above his society has led him to identify his wishes with those of his god to assert his authority over the whole Umuaro by means of Ulu's oracular power, created dissatisfaction among his people. The strife in Umuaro, narrated in the novel in a retrospective manner, was between the villages of Umuachala, Ezeulu's village and that of Nwaka of Umunneora. The reactionary forces within the tribe are suggested in the rivalry between Ezeulu and Nwaka, a wealthy titled man and a follower of Ezidemili, the Chief Priest of the god Idemili, one of the deities displaced by Ulu. The rivalry brought internal division of the tribe which is reflected in the debate over the issue of a disputed plot of land. In the assembly, before the outbreak of hostilities, Ezeulu spoke against Umuaro's claim over the plot of land as from his late father he knew Okperi to be the real owner of that land. But Nwaka and his followers, holding the opposite view, interpreted it as Ezeulu's biased attitude towards his motherland and won the support of the majority of the people. Umuaro's representative to Okperi, while asserting Umuaro's claim over the plot of land, committed blasphemy by damaging the image of the personal god of Ebo of Okperi and thereby lost his life. In the council of war, convened to discuss measures against Okperi, Ezeulu advised his people against fighting an unjust war. But Nwaka refused to accept Ezeulu's authority stating that the role of the Chief Priest should be strictly limited to his religious rituals and that it was not necessary to seek his permis sion to wage war - a clear hint at the internal strife in the community. Nwaka won the debate; the war against Okperi lasted for five days and finally stopped at the intervention of Winterbottom, the District Officer who gained the name 'Breaker of Guns' (37) among the people of Umuaro. In the subsequent hearing arranged by Winterbottom, Ezeulu testified against the claim of his own people over the disputed land as a result of which the land was awarded to Okperi. Ezeulu viewed the verdict as a divine retribution on Umuaro for challenging its deity: "Umuaro challenged the deity which laid the foundation of their villages. And - what did they expect? - he thrashed them, thrashed them enough for today and for tomorrow!" (14).

Ezeulu's ambition for power has prompted him to send Oduche, his third son to mission school defying the traditional custom. In his words: "I want one of my sons to join these people and be my eyes there. If there is nothing in it you will come back. But if there is something there you will bring home my share." (45). Although the desire for power is the prime motive, Ezeulu's speech reveals a realisation of the futility of the attempt to resist the white man. As change appears to be inevitable he seeks to master certain forces to retain his position. With the acumen of a shrewd politician he enters into alliance with the white man to promote his own cause - to alter his passive authority into an active one. He seeks to accommodate some changes in the society so that he can preserve his order, religion and tradition which may ultimately help him to regain his power.

Ezeulu's effort to exploit his friendship with the white man is not without repercussion. The sacrilege committed by his converted son in attempting to kill the royal python has been a blow to Ezeulu's image in the clan. At the instigation of Mr. Goodcountry, who has encouraged the converts to kill the sacred python to show their Christian spirit, Oduche puts it inside his footlocker. This incident symbolically presents the plight of the traditional religion under the overwhelming pressure of Christianity. By releasing the exhausted python in the presence of a big crowd Ezeulu makes himself vulnerable to attacks by his tribesmen. This incident has intensified the strife between the villages of Ezeulu and Nwaka for the python is sacred to Idemili, the principal deity of Nwaka's village. In violent rage, Ezeulu expels the messenger of Ezidemili, the priest of Idemili and Nwaka's friend who wants Ezeulu to purify his house of the abomination that Oduche has committed. In fact, Ezeulu himself is confused for the incident is unprecedented. But his refusal to punish Oduche is considered as further evidence of his alliance with the white man at the cost of his own people.

In spite of his strong individualism, Ezeulu is firmly attached to the traditional office of his priesthood. This understanding has caused his imprisonment by the British authority as he rejects the offer of appointment of Warrant Chief in Umuaro. He calls his people together to inform them of the invitation from the white man for him to go to Okperi, a journey which may keep him away from Umuaro for a longer period. As Nwaka predominates the assembly, Ezeulu fails to win the support from the elders and titled men in his confrontation with the white man.

During his imprisonment at Okperi, for not accepting the offer of British administration, Ezeulu, in bitter resentment, contemplates revenge on his clan who made no effort to prevent his humiliation. He is fully convinced of Ulu's wish to punish the community for defying his priest. The dream 
in which Umuaro openly insults Ulu re-enforces Ezeulu's desire. He dreams of Nwaka asking: "Is there anybody here who cannot see the moon in his compound? And anyhow what is the power of Ulu today?" (159) and then some people spat on the face of the Chief Priest and "called him the priest of a dead god." (159). This horrifying dream resolves all his doubts and makes him realise that his quarrel with the white man is insignificant compared to the wrong against him by his own people. The white man unknowingly becomes his ally in his struggle against his clansmen: "The longer he was kept in Okperi the greater his grievance and his resources for the fight." (176)

But the villager's overwhelming welcome to Ezeulu on his return to Umuaro undermines his thoughts of revenge and makes him to review the implications of his position as the Chief Priest. He is reconciled with his office of priesthood with a new understanding of his social responsibility : "Yes, it was right that the Chief Priest shall go ahead and confront danger before it reached his people. That was the responsibility of his priesthood." (189). It is the only time in the novel that Ezeulu sees himself as the representative of the people who have created both god and priest. The traditional Igbo warning - "no man however great can win judgment against a clan" (131) has proved to be his source of strength. After effecting a compromise between his humanity and divine roles, Ezeulu no longer feels the need to show that his power over the tribe is absolute. (Carroll 112)

But this new found sense of social obligation has not remained long in Ezeulu. While pursuing thoughts on his struggle against the clan and possibility of reconciliation he is "not allowed to remain in two minds much longer." (Arrow of God 191). Ulu himself intervenes directly bringing an end to all his doubts and confusions: "Ta! Nwanu !' barked Ulu in his ear, as a spirit would in the ear of an impertinent human child. 'Who told you that this was your fight?" "(191).

The divine half of his nature, reinforced by his desire to punish the community, makes him again the sole servant of Ulu without any consideration for his people: "It was a fight of the gods. He was no more than an arrow in the bow of his god. This thought intoxicated Ezeulu like palm wine."(192). He resolves to use the weapon offered to him by the British authority in the form of long imprisonment to punish Umuaro villagers for their divided loyalty towards Ulu and Idemili. He decides to attack his people at the most vulnerable point - the Feast of the New Yam. In due course, he refuses to announce the day for holding the Feast which controls the harvest : "I only call a new festival when there is only one yam left from the last. Today I have three yams and so I know that the time has not come." (207). On behalf of Ulu he seeks to make them wait for another two moons to enable him to eat the remaining sacred yams. As it is against the custom to collect harvest without celebrating the Feast, the yam starts rotting under the ground. Ezeulu thus exercising his absolute authority over the tribe remains implacable. Though inwardly he writhes in pain at the sufferings of the people, he consoles himself considering it to be a divine retribution: "It could not be my wish to make the smallest man in Umuaro suffer. But this is not my doing. The gods sometimes use us as a whip." (208). Nevertheless Soyinka considers this decision of Ezeulu to be an expression of his ambition for power:

Yet this priest aspires to no less than cosmic control. The six villages, as a result of an unfruitful consultation, would be locked in the old year for two moons longer. The grandeur of his challenge is only mildly tempered by the specious calculating game of numbers upon which it rests - the fact that there are three yams left instead of one. Again we encounter the priest's dogged secularisation of the profoundly mystical. (Soyinka 91)

The conflict between communal and individual perception of religious duty is reflected in the discussion between the elders of Umuaro and Ezeulu. The elders ask the Chief Priest to take action to end the sufferings of the people. They insist that Ulu, their god "does not want Umuaro to perish. We call him the saver." (207). To solve the crisis arising out of Ezeulu's imprisonment, they have offered him a practical suggestion by asking him to eat the remaining yams immediately without waiting for the new moon. Ezeulu rejects their proposal : "Those yams are not food and a man does not eat them because he is hungry. You are asking me to eat death." (Arrow of God207). Thus, Ezeulu remains adamant upholding his own interpretation of Ulu's divine will.

Achebe records the transitional point by highlighting Ezeulu's rigid stance that has increased murmurs of rebellion among the villagers. The missionaries, who are no longer considered as enemies, have seized the opportunity to proffer their own harvest festival in lieu of the New Yam Festival denied to Umuaro by Ezeulu. As the suffering of 
the villagers increases, the news of this offer spreads rapidly among the people.

The climax of the novel is reached with the death of Obika, the proudest of Ezeulu's sons who dies while performing the role of night spirit in a second burial ceremony of a villager. In the prevailing situation in Umuaro, there is only one interpretation of this event - Ulu disapproves the conduct of his Chief Priest. Ezeulu, who has been firmly convinced of his role as an arrow of Ulu, is also greatly shocked and perplexed at the punishment inflicted on him even after obeying the command of Ulu. As the incident is a total breakdown of his all convictions, he becomes mad and lives out his last days "in the haughty splendour of a demented high priest." (229).

Obika's death is, in fact, a legitimate outcome of Ezeulu's decision to postpone the Feast of New Yam. He was sick while asked to perform as Ogbazulobodo, the night spirit who chased away evil spirits. Despite his illness he agreed to it realizing the growing indifferent attitude of the villagers who had been suffering hardship because of Ezeulu's decision to postpone the New Yam Feast.

The Christian harvest which takes place a few days after Obika's death draws more people than Mr. Goodcountry has expected. The people ofd Umuaro have sent yams through their sons to offer to the new religion to gain the promised immunity. In this way, the custom of harvesting in the name of the son begins in Umuaro paving the way for the new religion to establish itself firmly in Africa displacing the indigenous native religion.

A thematic analysis of the novel clarifies the fact that in the interpretation of divine will, Ezeulu cares only for his individual power and forgets the responsibility and obligation of his office towards the people. He considers himself to be excluded from divine justice for committing no $\sin$. Thus, he fails to realise the mysterious nature of divine justice that punishes the whole community - guilty as well as innocent, for the sins of the individuals within it. Although a spiritual leader of the community, the incomprehensibility of divine order of justice remains with Ezeulu to the end.

\section{CONCLUSION}

Arrow of God is Chinua Achebe's successful endeavour to recreate the traditional African (Igbo) society along with the dynamic spirit of a vibrant living community. Ezeulu's decision to postpone the New Yam Festival asserting his power and with the motive of avenging his opponents, strikes a discordant note in the communal life. The irony in the situation - the protector of the community acting as a dis rupting agent bringing disaster to his own people leaves a lasting impression on the reader's mind. The transitional moment of shifting from the indigenous religion to Christianity due to the internal conflicts and disharmony is brilliantly captured by Achebe with amazing artistry and equitability.

\section{REFERENCES}

[1] Achebe, C. (1987). Arrow of God. London: Heinemann.

[2] Carroll, D.(!970). Chinua Achebe. New York: Twayne Publishers.

[3] Soile, S.(1976). "Tragic Paradox in Achebe's Arrow of God ." Phylon Vol. 37, No 3,3 ${ }^{\text {rd }}$ Qtr. 283-295.

[4] Soyinka, W.(1976). "Ideology and the Social Vision (1)." Myth, Literature and the African World. Cambridge: Cambridge University Press.

[5] Vargo, Edward P. (1978). " Struggling with a Bugaboo: The Priest-Character inAchebe and Greene and Keneally." In C.D. Narasimhaiah(ed), Awakened conscience: Studies in Commonwealth Literature. New Delhi: Sterling. 